\title{
EHUko Pedagogia Gradua lanbide anitzetarako prestatzen: ikasleen asebete eta iritzietan eta irakasleen pertzepzioan oinarritutako analisia
}

\author{
Preparing EHU degree of pedagogy for diverse occupations: an analysis of \\ the satisfaction and opinion of the students and the perception of the faculty \\ Jon Altuna Urdin*, Alba Madinabeitia Ezkurra, Inazio Marko Juanikorena, \\ Ana Aierbe Barandiaran, Esther Cruz Iglesias \\ Hezkuntza, Filosofia eta Antropologia Fakultatea, \\ Euskal Herriko Unibertsitatea/Universidad del País Vasco, Donostia, Gipuzkoa
}

\begin{abstract}
LABURPENA: Unibertsitatea da herritarren formakuntzan eta profesionalizazioan hezkuntza-instituzio aitzindaria, eta horregatik Pedagogia Graduari eginkizun garrantzitsu horretan prestakuntzaren kalitateari buruz hausnartzea egokitzen zaio. Pedagogoaren lanbideak badu berezitasun bat: hezkuntzako aditu gisa, tradizioz eskola-testuingurura mugatu izan du bere jarduna baina hezkuntza formaletik harago espazio potentzial ugari ditu. Horrekin batera, ordea, bere lekua mugatzeko zailtasuna agerikoa da. Hortaz, XXI. mendeko pedagogiari dagokio bere lan-esparrua birdefinitzea eta formakuntza orientatzeko erronka. Artikulu honen helburu orokorra izan da Euskal Herriko Unibertsitateko (UPV/EHU) Pedagogia Graduko ikasleek eta irakasleek, profesionalizazioaren mapan zehatutako lan-arloak kontuan hartuz zenbateraino hautematen duten koherentea dela graduan eskaintzen den prestakuntza aztertzea. Lagina 131koa izanik, Pedagogia Graduko 4 mailako 83 ikaslek eta gradu bereko 48 irakaslek parte hartu eta Likert eskaladun galdetegia bete dute. Ikasleen beharrak abiapuntu hartuta azterlan deskribatzaile eta esploratzailea burutu da. Emaitzek erakusten dutenez, ikasleen balorazioa irakasleena baino baxuagoa da pedagogiako irakasgaiak pedagogoaren lanbide-irteeretan duten posizioari begiratzen bazaio, eta bien ustez, jasotako prestakuntzan zein lan munduan errepresentazio handiena duen eremua «Ikerketa eta Hezkuntza» da. Aldiz, «Gizartea eta Kultura» eta «Prestakuntza eta Enpresa» gutxien ordezkatutakoak dira. Emaitza hauek orientabideak ematen dituzte etorkizunean Pedagogia Graduaren hobekuntzan eta pedagogoaren lanbide-profilaren zehaztasunean aurrera egiteko.
\end{abstract}

GAKO-HITZAK: pedagogia, goi-mailako hezkuntza, hezkuntza profesionalak, ikasleak, irakasleak.

\begin{abstract}
The spaces that the profession of the Pedagogue has occupied over the years in society has been changing, complicating the identification of his field of work. For this reason, it is up to the pedagogy of the twentyfirst century to make the transition to go one step beyond the traditional vision of work in formal education towards the challenge of defining and guiding its fields of work. The main objective of this article is to analyze the extent to which the Degree of Pedagogy of the University of the Basque Country prepares more or less for professional outings in a coherent way according to the opinion of the students and the faculty. Descriptive and exploratory research has been carried out on the needs of the students. In particular, the analysis and comparison of the opinion that both teachers and students have on the preparation of students for the different professional outings identified. The results show that the assessment of students on preparation for the professional fields is lower than that perceived by teachers. For both groups the training received is mainly aimed at the field of «Research and Education» with the other two areas of «Society and Culture» and «Training and Enterprise» that are less represented or worked.
\end{abstract}

KEYWORDS: pedagogy, higher education, education professionals, students, faculty.

* Harremanetan jartzeko / Corresponding author: Jon Altuna Urdin. UPV/EHU unibertsitatea. Hezkuntza Zientzien Saila. Hezkuntza, Filosofia eta Antropologia Fakultatea. Tolosa Hiribidea 70. 20018 Donostia. Gipuzkoa. - jon.altuna@ehu.eus - https:// orcid.org/0000-0002-1847-8083

Nola aipatu / How to cite: Altuna Urdin, Jon; Madinabeitia Ezkurra, Alba; Marko Jaunikorena, Inazio; Aierbe Barandiaran, Ana; Cruz Iglesias, Esther. (2020). «EHUko Pedagogia Gradua lanbide anitzetarako prestatzen: ikasleen asebete eta iritzietan eta irakasleen pertzepzioan oinarritutako analisian. Tantak, 32(2), 51-74. (https://doi.org/10.1387/tantak.21899).

Jasotze-data: 2020/07/06; Onartze-data: 2020/09/17

ISSN 0214-9753 - elSSN 2444-3581 / (c) 2020 UPV/EHU

(c) (i) Obra hau Creative Commons Atribución 4.0 Internacional-en lizentziapean dago 


\section{SARRERA}

Unibertsitatea herritarren formakuntzaz eta profesionalizazioaz arduratzen den goi mailako hezkuntza-instituzio liderra da. Horregatik egungo testuinguruak planteatzen dituen behar sozial, ekonomiko eta hezitzaileei erantzuteko, planteamendu zaharkitu zein estatikoetatik ihes egin eta konplexutasunari aurre egingo dioten estrategietan ipini beharko luke indarra (Collini, 2012; Boulton eta Lucas, 2011; Fullan, 2002; Hargreaves, 1999). Hori dela eta, derrigorrezko ariketa da Pedagogia Graduak eskaintzen duen prestakuntzaren kalitateaz eta garrantziaz galdekatzea unibertsitateko graduatuak, gizarte- eta lan-munduan ahalik eta ondoen sartzeko (Biggs, 2005; Riera eta Civis, 2008).

Azken hamarkadan Pedagogia Graduaren norabidea ikertzen ari diren lanek adierazten dutenez (Cardona, 2011; González-Lorente, Martínez-Clares eta González-Morga, 2015; Rosales, Torres, Sánchez, Jiménez eta Cabezas, 2018; Sánchez Morales eta Vega, 2019), gaurko errealitaterako pedagogiak elkarrekin uztartzen diren bi erronka nagusi ditu. Batetik, hezkuntza problematikekin konektatuta dagoen eremu formatiboa berrindartzea, eta bestetik, esparru profesional zein sozialean kokapen argi bat definitzea. Hain zuzen ere, premiazkoa da lanbide-esparru plural eta dinamikoari erantzungo dion prestakuntza eskaintza gaurkotua, eraginkorra eta erakargarria egitea.

Erronkak seinalatuta, aipamen berezia egiten zaio pedagogoaren lanbide-profilari. Izan ere, pedagogoak, hezkuntzako aditu gisa, eskola-testuingurura mugatu izan du bere jarduna, eta bitartean beste profesional batzuek, hezkuntza-eremutik urrun, pedagogiari zegozkion funtzioak bete izan dituzte eskolatik harago (González-Lorente et al., 2015). Hortaz, denborarekin arlo profesionalean pedagogoek bete ditzaketen lekuak aldatuz eta zabalduz joan dira, eta aldakortasun horrek, neurri batean, identitate profesionalean nolabaiteko krisia sortu du (Touriñan, 2018). Hala ere, pedagogiak eta, horrekin batera, pedagogoaren figurak esparru profesionalean dituen ahalmen eta mugei buruzko bereizketa argia antolatzen eta ezartzen ahalegindu behar dute, hezkuntza gaur egungo gizartean aldaketa sustatzeko eragile nagusia baita (Torres Sabaté, 2015).

Pedagogiaren egokitzearen ardura horri aurre egiteko asmoz, badira jada urte batzuk UPV/EHUko Hezkuntza, Filosofia eta Antropologia (HEFA) Fakultatean eskaintzen den Pedagogia Graduan profesionalizazioan zentratutako ikerketa eta ekinbide iraunkor bat zabaldu eta bideratzen hasi zenetik. Lan-ildo honi PedaPro Proiektua izena eman zaio, eta berezko izaera eta izen propioak hartu duten azpiproiektu ezberdinetan garatuz joan da. Azkena, eta artikulu hau zentratzen duena, PedaLan proiektua izan da. Artikulu honetan EHUko Pedagogia Graduari begirada gaurkotua eta sistematizatua eskaintzen zaio, hain zuzen ere, ariketa kronologiko batean bilduz orain arte inplementatu diren pro- 
fesionalizazio-estrategiek titulazioaren hobekuntzan izan duten eragina. Profesionalizazio ekinbidea doitzeko ezinbestekoak izan dira azken 6 urteetan graduko 4. mailako ikasleriari eman zaien asebetetze inkesta. Emaitza hauetatik eratortzen dira Pedagogiako graduaren behar eta hutsuneen azterketa abiarazteko datuak.

Ikerketa prozesua gidatu duten galderak honako hauek izan dira: Pedagogia graduko irakasgaiek gaur egun euskal jendarteak behar dituen pedagogoak trebatzen al dituzte? Modu argian hautematen al dira graduan zehar pedagogoen irteera profesionalak? Zein da ikasleriaren eta irakasleriaren pertzepzioa? Analisia errealitate espezifikora egokitutako irakurketa teoriko batetik abiatzen da, pedagogoaren profil profesionala, pedagogia gradua eta azken honen funtzio zein lanbide-irteeren inguruan hausnartuz. Ondoren atal enpirikoari heltzen zaio, perspektiba diakroniko batetik ikerketaren testuinguruan murgilduz eta PedaProMap abiapuntutzat duen proiektuaren ezaugarri nagusiak eta mapa azalduz. Horrekin batera, aztergaiarentzat garrantzia berezia duen PedaLan proiektuaren datuak eta emaitzak aztertuko dira, etorkizun hurbilean profesionalizazioaren esparruan titulazioa hobetzeko gakoekin amaituz.

\subsection{Pedagogoaren profil profesionala Europako Hegoaldean: dialektika zabaletara igarotzeko beharra}

Berriki hamarkada bi bete dira Goi-mailako Hezkuntzaren Europako Esparruari (GHEE) bide eman zion Boloniako Adierazpena sinatu zenetik (Marquand eta Scott, 2018). Europako lurralde erkidean unibertsitarioen fluxua erraztea asmo zuen egiturazko makroerreforma izan zenak, eskaintza formatiboa birpentsatzeko eta mudatze horretan ikasleen irteera-profilaz lokalki hausnartzeko arraildurak ireki zituen gurean. Urteotan, Pedagogiak bezala, titulazio ugarik erronka berriei aurre egin behar izan diete, esaterako, gradu eta graduondoko egiturari, ECTS sistemari, titulazio berriaren diseinuari eta honekin batera, konpetentzien bidez ikasteko metodologia aktiboen eklosioari (Eizagirre, Altuna, Pikabea, Marko, eta Pérez, 2017; Europako Batzordea, 2015). Hortaz, EHUko Pedagogia graduak bere esparru profesionalaren proiekzioari begira egun duen kokapena zein neurritan egonkortu den galdetzeak egokia dirudi, atzera, titulazioa etengabe hobetzeko argibideak bilatu nahi badira (Marko et al., 2019).

Jendarte globalizatu batean bizi gara eta geroz eta ohikoagoak dira ekonomiaren eta kulturaren ikuspegitik estandarizaziorako saiakerak, eta goi-mailako formakuntzan, espezializazioa bihurtu da ipar (Boulton eta Lucas, 2011). Faktore ugarien interdependentzia sortzen den honetan, pedagogiako profesionalentzat aukera berriak zabaldu zitezkeen arren, berezitasunak ezabatzeko arriskua ere badago. Testuinguru honetan, pedagogia egoera berezian aurkitzen den diziplinetako bat da, bere profil, funtziona- 
litate eta lan jarduerari begiratzen bazaie. Izan ere, historikoki zaintza figurari, eskolari eta irakaskuntza funtzioari lotua dauzkaten erroek zailtzen baitiote beste esparruetan identitate propioarekin ernatzea (Rosales et al., 2018). Alta, Pedagogia ikaskuntza eta irakaskuntza prozesuen elementuak aztertzen dituen zientzia izaki, hezkuntza formalaz harago tokitzen diren enpresa-eremuan edota arlo sozialean ere proiektatzen du bere ezagutza eta profil profesionala.

Hori dela eta, egungo errealitateari begira pedagogiaren paideia adiera klasikotik (paidos, etimologikoki haurra esan nahi duena eta agein, gidatzea edota bideratzea) andragogiak duen esangura zabalera (pertsona etengabe heztea) igarotzea ezinbestekoa dirudi (Knowles, 1972), baldin eta pedagogoaren irudi soziala eskura duen eremu profesional heterogeneo bezain anizkunarekin konektatu nahi bada (Touriñan, 2018). Trantsizio honek galaraziko lituzke, beraz, Pedagogian graduatuaren funtzioei atxikitzen zaizkion nahasketa edota anbiguotasuna; eta bide batez, pedagogoak hezkuntza-prozesu ororen gainean duen profesionalizatze-profila finkatzea ere ekar lezake bere izaera hibridoa eta erlazionala aitortuaz (Navarrete, 2008; Riera eta Civis, 2008; Rosales et al., 2018).

Pedagogoaren funtzionaltasunari lotutako berezitasun honen eskutik dator beste paradoxa. Izan ere, Hezkuntza Administrazioak ez du pedagogoentzat berariazko lanbide-irteera zehatzik sortu eta, aldi berean, pedagogiako profesionalari esleitutako funtzio eta enplegu-sorguneak egunero zabalduz doaz (Ruiz de Miguel eta García de la Barrera, 2013). Touriñanek (2018) pedagogiaren irudi soziala jendarte baten hezkuntza kalitate mailarekin erlazionatzen du, funtzio pedagogikoa baldintza soziohistoriko batzuen barruan ematen delako beti. Hortaz, testuinguru hurbilean hezkuntzaren ezagutzari ematen zaion garrantziari erreparatu beharko litzaioke hobeto ulertzeko egun existitzen den pedagogiaren esanahia eta jarduera-eremuaren ezjakintasun zabaldua; eta, hortik aurrera, pedagogiak diziplina moduan eta unibertsitateko gradu bezala duen etorkizuna sakon berrikustea da afera (Herrán, 2012; Touriñan, 2018).

Pedagogia profesioaren nazioarteko proiekzioa babesten duen Europako Pedagogo Profesionalen Federazioak (Fédération Européenne des Professionels de la Pédagogie) 2013an Concepció Torres Sabaté Pedagogia Doktorearen gidaritzapean lanbide-profilari buruzko ikerketa bat burutu zuen. Galdeketa bat betearazi zitzaien ikerketan parte hartu zuten erakunde bakoitzeko pedagogoei beren profil profesionalak aztertzeko, eta erantzunetatik hauxe ondorioztatu daiteke: Europa hegoaldeko pedagogiaren lanbidea soilik eskola ingurunera lotu eta mugatzen zuen mito zaharrarekin apurtu behar da. Emaitzen artean, esku-hartze pedagogikorako lau eremu definitzeaz batera, inkestatutako pedagogoen interes profesionalen arabera antolatu ziren eremuok: pedagogia soziala, hezkuntzapedagogia, pedagogia transbertsala eta erakundearen pedagogia (Torres Sabaté, 2015). 
Globalizatutako jendarte batek, beraz, erronka kultural eta sozial geroraezinak ditu. Euskal jendarteak horretaz aski ongi daki, eta pertsonon zein formakuntza-prozesuen aniztasunaren kudeaketa horretan pedagogoaren egokitasun profesionala eta heterogeneotasuna babestearekin batera, eskakizun horiek graduan zehar ordezkatzeak premiazko eginkizuna dirudi. Zertarako eta bere profil profesionalaren eraikuntzan akuilu diren entzute aktiboa, enpatia maila altua, komunikaziorako trebetasunak, kritika eta antolakuntza gaitasuna, egokitasun maila altua, talde lanerako gaitasuna eta autonomia bezalako konpetentziak egon daitezen pertsonen, taldeen eta gizarte eragileen konplizitatearekin batera, hezkuntza aldaketa sustatzera bideratuta.

\subsection{Pedagogiako gradua forman eta edukian: aldaketen kronologia bat}

90eko hamarkada amaieratik Europako konbergentzia prozesuak konpetentzietan oinarritutako ikaskuntzaren ikuspegia ekarri zuen eta unibertsitateetako eskaintza formatiboa modernizazio fase baten erdian kokatu zuen (Europako Batzordea, 2015). Ordutik hona, ikaskuntza emaitzen bidezko artikulazioak ikastaldia amaitzean ikasleak ezagutu, barneratu eta frogatzeko gai izango dena definitzeko lana ekarri du. Birdefinitze prozesu horien ebidentzia da EHUko Pedagogia ikasketen titulazioa forman zein edukian aldatu dena (Eizagirre et al., 2017). Formakuntza gehiago profesionalizatzea ekarri dute bai irakastaldian eta urte kopuruan eman den trinkotzeak, baina baita curriculumaren modulukako barne-egituraketan eta lan-esparru berriei zuzenduta eskainitako irakasgaien aniztasunak eta diziplinartekotasunak ere (Marko et al., 2019).

Europako goi-mailako hezkuntza erreforma hasi baino lehen Estatu Espainolean Pedagogia graduari lotutako eduki mailako aldaketa gertatu zen. 915/92 Errege Dekretua onartu zenetik (1992ko abuztuaren 27ko Estatuko Aldizkari Ofiziala) eta berarekin Pedagogia titulazioaren gutxieneko irakaskuntzak ezarri zirenetik, estatu osoan irakatsi beharreko enborreko gaien mapa bat diseinatu zen, titulazioa osatzen zuten irakasgaiak berdinak izanik (behintzat, nomenklaturari dagokionez).

Halere, urteen joanean Estatu Espainoleko Pedagogia lizentziaturako ikasketa plana ordezkatzen zuten gai komun hauek unibertsitate batetik bestera aldatzen hasi ziren. Izan ere, fakultate bakoitzak konfiguratzen dituen derrigorrezko, hautazko eta aukera askeko ikasgaien diseinuaren araberakoak dira. Pedagogiaren eta Gizarte Hezkuntzaren liburu zurian ibilbide ezberdinak markatzen dituzten unibertsitateen eskaintza bilduta dago (Villa, 2004). Aniztasun honek pedagogiaren lan eremu berrien agerpena erraztu ahal izan du, baina aldi berean unibertsitate espainiarren artean pedagogiako ikasketa planen baliozkotzeak ere eragotzi ditu (Vi1la, 2004). 
Geroztik, ANECAk (2005) pedagogia tituluaren diseinu berriaren alde egin du, non unibertsitate guztiek enborreko irakasgaien $\% 60$ bete behar duten eta $\% 40$ beren testuinguru eta lortu nahi duten profil profesionalaren neurriko hautua egin behar duten (ANECA, 2005).

Urte bat geroago Hezkuntza eta Zientzia Ministeriotik (MEC, 2006) Estatu Espainoleko unibertsitate mailako ikasketen antolamendua proposatzen da gradu eta graduondoko unibertsitate-tituluen sorrera berriari ildoak ezarriz. Egituraketa berrian goi-mailako hezkuntzaren agertoki berria eta Boloniako Adierazpenetik (1999) eratorritako gradu berriak indarrean sartzea aintzat hartzen da (MEC, 2008).

Marko berri honetan, aurreko Pedagogiako lizentzia 5 kurtsotik 4ra igaro zen, eta ikasketa planak eta irakasgaiak berriz antolatu ziren. Murrizketa honek garai bateko ibilbideetan murrizketa esanguratsua ekarri zuen, bai eta hautazkoen eta aukera askeko ikasgaien desagerpena ere. Horren haritik, nahiz eta esfortzu handiak egin diren esku-hartze eremua birdefinitzeko pedagogoaren irteera profesionalen mapa sortuz (Marko eta Altuna, 2016), pedagogiaren espezializazioa hainbeste txikiagotu da ezen zaila den Pedagogian graduatua denari lanbide-irteerak zehaztea.

Honetara ezkero iparra argia da. Pedagogiako gradudunek beren formakuntza bi norabidetan garatu beharko lukete; bat, hezkuntza ezagutzaren inguruan nork bere epistemea eraikitzeko eta ezagutza diziplinarra zabaltzeko hezkuntza-zientzien bidean; eta bi, testuinguru errealetako beharrei erantzuteko lan merkatuak egiten dituen eskaeren bidean. Horregatik pedagogiaren formakuntzak helburu bikoitza du. Lehenengoa hezkuntza fenomenoa bere osotasunean aztertu ahal izateko formakuntza teoriko-praktikoa ematea, aldi berean, hezkuntza-sistemen eta prozesuen garapenerako, antolamendurako eta analisirako printzipioak ezagutzeko aukera emango diona. Eta bigarrena, esku-hartze eremu zehatzetan (sozialean, eskolakoan, enpresakoan, eta abar) proiekzio profesionala ahalbidetuko dion formakuntza praktikoa eta balio anitzekoa eskaintzea.

Gaur egun pedagogoaren irteera profesionalen eremuan dagoen definiziorik eza gainditzeko, eta baita hezkuntza-zientzien ezagutza eta aplikazio mailan dauden behar formatiboak betetzeko ere, pedagogoaren profil akademikoari - eta hedaduraz soziala eta lanbidekoa ere denari- buruz ikertzen jarraitzeak nahitaezkoa dirudi, hau baita pedagogoaren iruditeria soziala hobetzeko eta jendarte mailan bere figura errekonozitzeko modua (Touriñan, 2018).

\subsection{Pedagogiaren funtzioak eta lanbide-irteerak: Laneko Pedagogia gorantz datorren arloa al da?}

Pedagogiaren funtzioak aztergai izan dira urte luzez, eta oro har, esan genezake pedagogo baten eginkizunak ikas-prozesuen garapena, antola- 
keta eta ikerketa direla (Torres Sabaté, 2015). Erreferentzia moduan erabili daitekeen adibidea Pedagogoaren Lanbide Estatutuan jasotzen diren funtzioak dira, 1986ko Pedagogoen III. Estatu Bilkuran onartuak izan zirenak (Benedito, Millan i Guasch eta Amadó, 1986). Bilkura honetan arlo profesional hauek definitu ziren: a) hezkuntza formalaren berezko funtzioak diren zentro baten zuzendaritza eta hezkuntza-sistemaren ikuskaritza, zerbitzu psikopedagogikoak eta hezkuntza-orientazioa, curriculum-materialak prestatzea eta diseinatzea; b) gizarte-esparruaren eta justiziaren berezko funtzioak, hala nola, errehabilitazio- eta gizarteratze-zentroetako lana, hezkuntza-administrazioa, hezkuntza terapeutikoa, hezkuntza berezia, haur-eskoletan, landa-eremuetan edo animazio soziokulturalean; edota d) prestakuntza-, berrikuntza- eta ikerketa-funtzioak, hala nola unibertsitate-irakaskuntza, hezkuntza-teknologia eta komunikabideak, ikerketa, eta hezkuntza-berrikuntza, irakasleen etengabeko prestakuntza eta helduen etengabeko hezkuntza.

Lan irteera horietako asko hezkuntza sistema formalarekin lotuta egon dira historikoki, eta ohikoak dira lehen hezkuntzako ikuskatzaileak, eskola-zuzendariak, pedagogia-irakasleak, bigarren hezkuntzako irakasleak eta unibertsitateko pedagogia-irakasleak (Viñao, 2008). Hala ere, aukera horiek denbora igaro ahala lausotu dira. Birdefinitze prozesu horretan, aukera berriak bilatu behar izan dira hezkuntza ez-arautuan, eta eremu horietan aurkitzen diren beste titulazio batzuk sartzen dira. Horregatik, pedagogoaren irteera batzuek hezkuntza formaleko zentroei lotuta jarraitzen dute, hala nola, ikastetxeetako zuzendaritza, kudeaketa eta orientabidea, nahiz eta horiek itunpeko edo pribatuak izatera mugatzen diren. Ohiko beste jarduera bat ikasliburuen edo material didaktikoa ekoizten duten enpresen argitalpenetarako curriculum-materialak diseinatzea eta egitea da. Era berean, pedagogoaren formakuntza zereginak komunak izaten hasi dira lan eta enpresa sektorean (Viñao, 2008).

Enpresen esparrua aspalditik dago pedagogiako irteera profesionalen jomugan. Horren adibide gisa, Pedagogoaren Proiekzio Profesionala Enpresan izeneko aztergaiari buruzko ikerlanean aurki daiteke (Viladot, 1992); eta honekin batera, Laneko Pedagogiari buruzko ikerketa, artikulu eta liburuetan ere bai (Fernández-Salinero eta De la Riva, 2016; Sánchez Morales eta Vega, 2019). Gaiari buruz eskuragarri dagoen literaturan, enpresako langileen etengabeko prestakuntzaren garrantzia azpimarratzen da (Aramburuzabala, 2012), eta lanerako aholkularitza didaktikoa egitea, enpresaren helburuak lortzeko prestakuntza-programen diseinua eta orientazioarekin batera, pedagogiaren profilarekin eta honen eskumen profesionalekin lotzen da (Pineda, 2002).

Era berean, enpresa-esparruan lan egiteko aukera horiek eskatzen dute arlo honetan gaitzen duten irakasgai bereziak dituen titulazioa. Eta, beraz, pedagogoek beren lan-aukerak handitu nahi badituzte, ezinbestekoa izango da pedagogiako gradu eta ikasketek enpresari eta lan-munduari buruzko 
ikasgai eta nozioak eskaintzea (Viladot, 1992). Orobat, pedagogia graduko curriculumaren eta erakundeen aniztasuna egokitzat jotzen dute hainbat autorek (González-Lorente et al., 2015), eta argudiatzen dute pedagogoek profesional gisa lekua badutela, eta XXI. mendeko beharretara eta gaitasunetara egokitzen den prestakuntza batera zabaldu behar dutela pedagogoek. Hala eta guztiz ere, ez dago dudarik gaur egungo gizartean pedagogia zereginen enplegugarritasunerako gaitasunak ardatz duen formakuntzan lan egin behar dela (Pineda, Ciraso eta Armijos, 2018).

\section{IKERKETAREN TESTUINGURU ENPIRIKOA: UPV/EHUKO PEDAGOGIA GRADUA ETA BERE BEREZITASUNAK}

Sarreran azaldu moduan, badira jada urte batzuk UPV/EHUko Hezkuntza, Filosofia eta Antropologia (HEFA) Fakultatean eskaintzen den Pedagogia Graduan profesionalizazioan zentratutako ikerketa- eta jarduera-ildo iraunkor bat zabaltzen eta bideratzen ari dela. Lan-ildo honek, beren ikasketen funtzio eta irteera profesionalei buruz ikasleengan antzemandako kezka eta ardura ditu oinarri.

PedaPro Proiektua izena hartu duen proiektuak erantzuna eman nahi dio elkarrekin erlazionatuta dauden bi bektoreei, alegia, formakuntzari eta figura profesionalaren sozializazioari. Batetik, pedagogia graduko ikasleriak adierazten duen behar bati erantzuten diolako, bere ikasketen irteera eta funtzio profesionalei buruzko orientazio gehiago eskatzen duenean. Eta bestetik, lan-ildo honek erantzun nahi diolako maiz aipatzen den beste hautemate bati ere, zerikusia duena pedagogo profesioaren ikusarazte sozialak duen zalantzazko pertzepzioarekin.

Ekinbide honen inguruan izaera ezberdina duten hiru fase edota jardunbide osagarri garatuz joan dira. Lehena, PedaProMap izenekoa, pedagogo profesionalen mapaketaren azterketa burutzeaz batera, pedagogiaren oinarrizko Profesionalizazioaren Mapa osatu eta orientaziorako baliabideak eta ekintzak ere norabideratu dituena (Marko eta Altuna, 2016). Bigarrena, Zeharka izenekoa, pedagogia graduko zeharkako gaitasunen azterketan zentratu dena. Eta, hirugarrena, PedaLan izenekoa, bereziki aztertu nahi izan duena Profesionalizazioaren Mapan definitutako espazio profesionalak noraino dauden graduan ordezkatuta eta zein neurritan lantzen diren espazio horiek graduko ikasgaietan zehar.

Lan-ildo horren baitan, 2014 urtean, Pedagogiako Graduko 4. mailako ikasleek graduari buruz duten pertzepzioa jasotzeko datu bilketa abiatu zen Fakultatean. Urtez urte, ikasleen iritziak eta balorazioak ezagutzeko hainbat talde-eztabaida egin izan dira eta urte amaieran ikasle guztiei galdetegi espezifiko bat eman izan zaie. Galdetegi horretan, titulazioaren aspektu ezberdinak (ikasketa plana, koordinazioa, baliabideak, praktikak, orientazioa...) baloratzeko eskatu izan zaie, 1-4 bitarteko eskalan. 


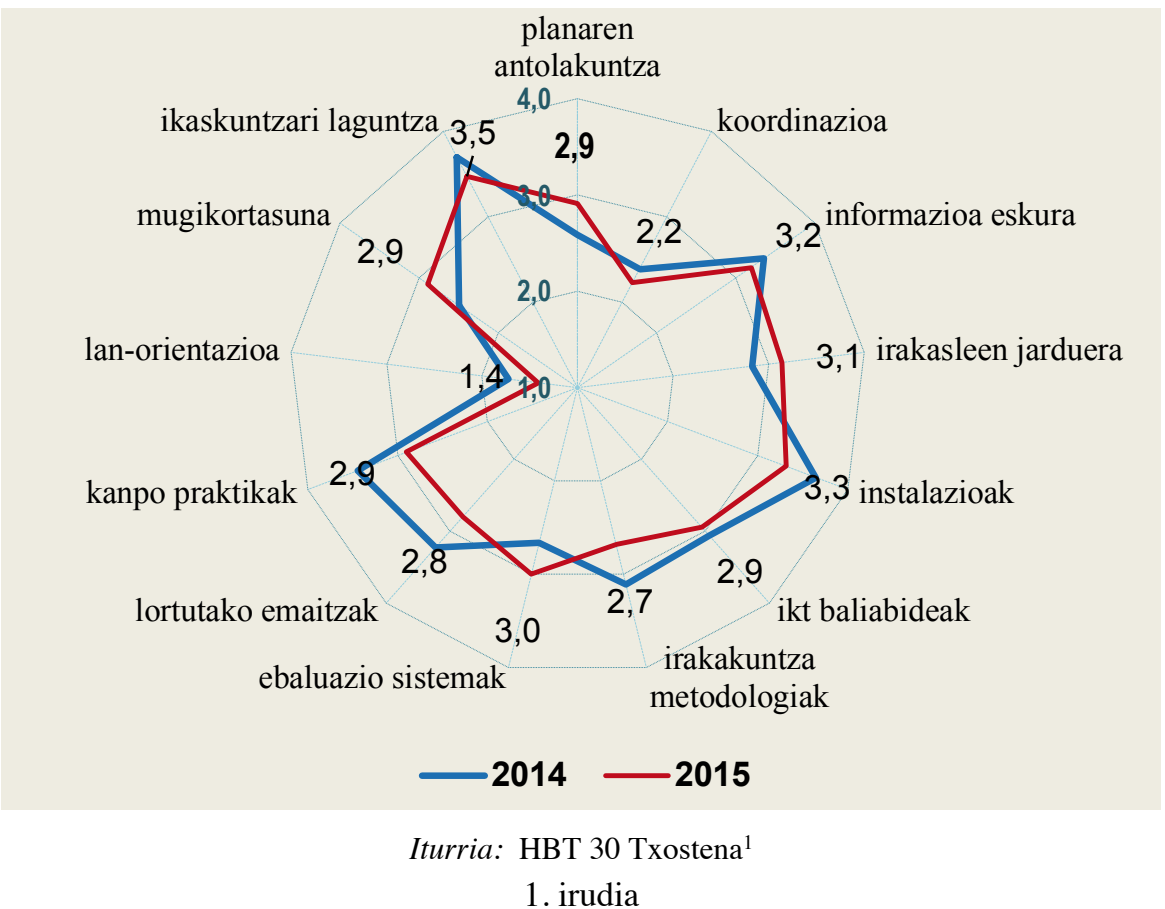

4. mailako ikasleen balorazioak. Puntuazioen batez bestekoak - 2014 - 2015

Ikasleen balorazioek 1. irudian erakusten duten moduan, 2014 eta 2015 urteetan lan-orientazioa izan zen dimentsio guztien artean ikasleek gutxien puntuatu zuten aldagaia. Datu horiek bat egiten dute beste ikerketa batzuek ere erakutsi izan dutenarekin (García-Alvarez, Sotelino eta Crespo, 2014), eta garbi islatzen dute egungo unibertsitate ikasleriak egiten duen eskakizuna, unibertsitateko ikasketetan lanerako orientazio eta formakuntza jarduerak areagotu daitezen. Egungo ikasleak bere ikasketen ahalbide profesionalak ezagutzeko beharra adierazten du eta, bide horretan, orientazio gehiago eskatzen du.

Lan-orientaziorako demanda horri erantzun nahian HEFA Fakultatean PedaPro Proiektua izena hartu duen ikerketa eta jardun lerroa garatu da azken urteotan. Lan-ildo honek, erantzun nahi izan dio, baita ere, maiz aipatzen den beste hautemate bati, pedagogoaren profesioaren ikusgarritasun sozial txikiarekin zerikusia duen pertzepzioari, hain zuzen ere.

${ }^{1}$ HBT30 Txostena: Pedagogia koordinatzailearen barne dokumentua. Egileak: Jon Altuna, Eider Pascual, Inazio Marko, Ana Aierbe, Esther Cruz, Alba Madinabeitia. PIE (2016-2018). Perfil profesional, centros de prácticas y ámbitos profesionales de la Pedagogía: definición, análisis y propuesta para la titulación. 
Aipatu xede nagusi horri begira, PedaPro lan-ildoa ekintzarako ikerketa gisa planteatu da, pedagogia titulazioa hobetzeko. Horren harira, ikuspegi metodologikoa ekintza-ikerkuntzarako ikuspegian oinarritu da, Kemmis eta McTaggart-ek (1988) ematen dioten zentzuan, hau da, aldaketa sustatu nahi duen praktikari buruzko eta praktika horren hobekuntzari buruzko ikerkuntza gisa ulertuta (Townsend, 2012; Figueroa eta Gomez, 2015). Ekintza ikerkuntzaren ikuspegi metodologikoaren berezko ezaugarriari jarraikiz, PedaPro lan-ildoa ziklo ezberdinez osatu den espiral moduko prozesu gisa garatu da.

PedaPro lan-ildoaren helburu nagusiak honako hauek izan dira:

- Egungo gizartearen beharretara egokitutako pedagogoen irteera profesionalak hobeto ezagutzea eta ezagutza hori graduan zehar hedatzea.

- Egungo gizartearen beharrei erantzuteko pedagogiako garapen profesionala lantzeko graduan hobetu edota indartu beharreko alderdiak identifikatu eta baliabideak sortzea.

- Ikasleen eta irakasleen pertzepzioa ezagutu eta hobekuntzarako baliatzea.

Lan-ildo honen lehen proiektu-zikloak PedaProMap izena hartu zuen. Abiapuntua, 2013an egindako esplorazio-azterketa izan zen, profesioaren ikusgarritasun sozial eskasaren pertzepziotik abiatuta pedagogoaren profesioak gizartean hartzen dituen lekuak ezagutzeko helburu espezifiko hauekin egindakoa:

a) Gaur egun eta Euskal Herrian pedagogoen lanbide diren espazio profesionalak identifikatzea eta horiei buruzko ezagutza eguneratzea.

b) Pedagogiako ikasleei orientazioa emateko baliabideak sortzea, beren ikasketekin lotutako espazio profesionalen eta aukera ditzaketen prestakuntza-ibilbideen ikuspegi argia emateko.

Pedagogoaren profilari, funtzioei eta espazioei buruzko esplorazio-ikerketa izan zen, mapaketa azterketa gisa «elur-bola» teknikaren bidezko laginketarekin egindakoa. Lagin horretan ia ehun profesionalen datuak jaso ziren, telefono bidezko elkarrizketen edota postaz bidalitako galdeketen bidez. Erantzunbanaketan \% 86,1 emakumezkoak izan ziren eta \% 13,9 gizonezkoak.

Azterketa horren datuen lanketan oinarrituta, hainbat produktu eta emaitza sortu dira. Nagusiki honako hauek:

\subsection{Profesionalizazioaren Mapa}

Azterketa horren emaitza nagusia lehen Pedagogiaren Profesionalizazioaren Mapa izan zen. Bertan, jasotako datuen analisian oinarrituta, gaur egun pedagogoak aritzen diren espazio profesional ezberdinak kategorizatu eta hiru arlo nagusitan sailkatzen dira. Mapa hau Pedagogia Graduko Batzordean egiaztatua eta talde-eztabaidan eguneratua izan da. 


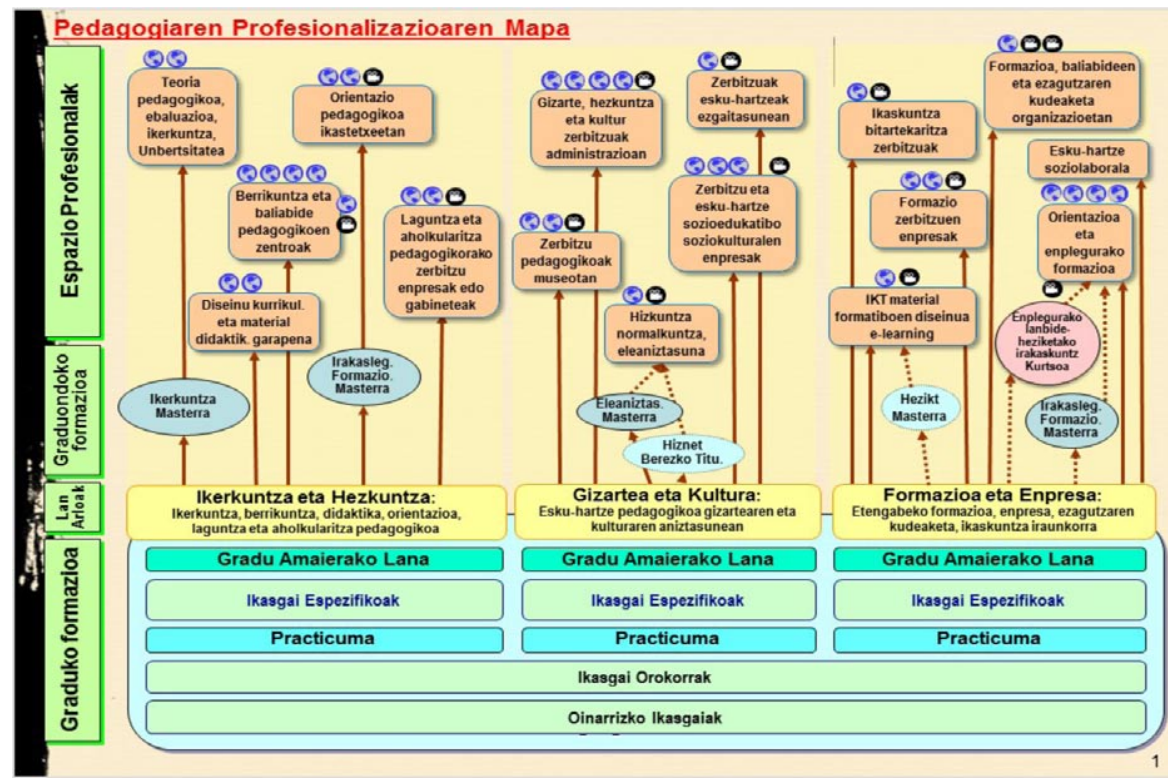

Iturria: (Marko eta Altuna, 2016)

2. irudia

\section{UPV/EHUko Pedagogiaren Profesionalizazioaren Mapa}

Mapak profesionalizaziorako ibilbideak izan daitezkeenak irudikatzen ditu. Hiru lan-arlo nagusi zehazten ditu (Ikerkuntza eta Hezkuntzaren arloa, Gizarte eta Kulturaren arloa, eta, Formakuntza eta Enpresaren arloa), eta horien barruan hamabost espazio profesional zehatz. Espazio guzti horietan egun pedagogoak aurki daitezke profesional gisa lanean. Maparekin lan eginez, ikasleak ikasketen eta lanbideen ikuspegi globala eduki eta bere ibilbide akademiko eta profesionalari buruz hausnar dezake. ${ }^{2}$

\subsection{Lan-orientaziorako baliabideak}

Profesionalizazioaren Mapatik abiatuta, eta mapari erreferentzia eginez, ikasleen orientaziorako hainbat baliabide sortuz joan dira. Hala nola, pedagogoekin egindako elkarrizketen bideo bat, espazio profesional ez-

${ }^{2}$ Mapa helbide honetan eskura daiteke: https://www.ehu.eus/eu/web/hefa/pedagogia 
berdinen arabera antolatutakoa, edota HEFA fakultateko web-orrian ${ }^{3}$ atal bat bideo horren mozketekin eta pedagogo bakoitzari dagokion arloari, espazio profesionalari, antolaketari eta funtzioari buruzko informazioarekin. Halaber, ikasleentzako orientazio-ekintzetan ere erabili izan da mapa, bai aurkezpen-azoketan edo ate irekien jardunaldietan, bai graduan zehar, arlo, profil eta enplegagarritasunerako orientazio desberdinak lantzeko.

\subsection{Enpresa eta erakundeen lokalizazioa mapan}

Profesionalizazioaren mapa erreferentziazko tresna gisa ere erabili da ikasleekin, errealitate sozio-profesionala ezagutuz beren etorkizuneko ibilbideari buruzko hausnarketa egin eta karrera profesionala diseinatzen laguntzeko. Horrela, ikasleek egindako ekarpenekin mapa osatuz joan da, Hego Euskal Herrian egungo irteera profesionalerako lantoki potentzial berriak islatuz eta mapan definitzen diren espazio profesionaletan jarduten diren erakunde edota enpresa errealekin taulak osatuz.

Zikloan zehar, 2014an abiatutako graduari buruzko ikasleen pertzepzioa jasotzeko datu bilketa egiten jarraitu da. Urtero laugarren mailako ikasleei galdetegia eman zaie titulazioaren zenbait aspekturi buruzko balorazioa egin dezaten.

Mapa eta mapatik eratorritako baliabideak garatu eta erabili ostean, mapan azaltzen diren espazioak eta titulazioan eskaintzen den formakuntza zein neurritan bat datozen edota elkarren artean koherenteak diren aztertzeko beharra antzeman zen. Horrek Pedalan proiektuaren zentzua eta beharra adierazten zuen.

\section{PEDALAN PROIEKTUAREN HELBURUAK ETA METODOLOGIA}

Aurreko zikloan egindako lanetan oinarritzen den PedaLan proiektu honen xede nagusia nagusia izan da aztertzea zenbateraino hautematen duten ikasleek eta irakasleek koherentea dela Pedagogia graduan eskaintzen den prestakuntza, zehazki, profesionalizazioaren mapan zehaztutako lan-arloetako (gizartean, hezkuntzan, enpresan, etab.) proiekzio profesionalean oinarrituta, edota eremu horietakoren batean neurri handiagoan edo txikiagoan ardazten ote den analizatuz. Zehazkiago, hauek dira bere helburu espezifikoak:

1. Ikasleen ustez graduan jasotzen duten formakuntzak pedagogiako zein esparru profesionaletan proiektatzen duen etorkizuneko jarduera profesionala ezagutzea.

\footnotetext{
${ }^{3}$ https://www.ehu.eus/eu/web/hefa/pedagogo-profesionalak
} 
2. Irakasle bakoitzak lantzen dituen irakasgaiak zein esparru profesionaletan hautematen dituen aztertzea.

3. Ikasleek eta irakasleek graduan emandako prestakuntzan lanbide-irteeren irudikapenari buruz duten pertzepzioan zer antzekotasun eta desberdintasun dauden identifikatzea.

Azterlan deskriptibo eta esploratzaile bat egin da, «ex post facto» ere deitua (Kerlinger, 1983). Bertan, parte-hartzaileak ezaugarri jakin batzuen arabera aukeratzen dira, eta ez da kausalitatea ezarri nahi, baizik eta zehaztu nahi da zer erlazio dauden (antzekotasunak eta desberdintasunak) Pedagogiako 83 ikasleen eta 48 irakasleen ikuspegiaren artean, hainbat lanbide-espaziotan, prestakuntzari eta lanbide-irteerekin duten harremanari buruz. Asmoa ez da hipotesi jakin batzuk betetzen direla frogatzea, baizik eta, Dendaluzek (1999) aipatzen duen eran, modu deskriptiboan eta esploratzailean eragileei dagoeneko gertaturikoak aztertzea; deskriptiboan, portzentaje, frekuentzia eta batezbestekoekin, eta, esploratzailean, ezagutza eta ondorio batzuetara iristea kasu edo fenomeno baten (Pedagogiako graduaren eta lan irteeren azterketa) hasierako ikerketa eginez. Horretarako, metodologia kuantitatiboa erabili da; bai ikasleek bai irakasleek galdetegi bana bete dute.

Guztira 131 parte-hartzaile izan ditu ikerketak, horietatik 83, Pedagogiako 4. mailako ikasleak, eta 48, gradu horretako irakasleak. Lagina ez-probabilistikoa eta intentzionala da (Hernández, Fernández eta Baptista, 2006); izan ere, parte-hartzaileak eskuragarri zeuden aplikazioaren unean, eta, gainera, ikerketan mugatutako zenbait irizpide betetzen zituzten, hala nola gradua eta maila akademikoa. Ikasleen ezaugarriei erreparatuz, horietarik 53 euskarazko taldekoak ziren eta 30, gaztelaniazko taldekoak. Ez zen genero eta adinaren aldagaien inguruan galdetu, ez baitzen helburua genero eta urteen arteko ezberdintasunak topatzea.

Ad hoc egindako galdetegi bat erabili da, aurreko zikloan garatutako fakultateko pedagogiaren profesionalizazioaren mapan oinarrituta (Marko eta Altuna, 2016), eta modu autoadministratuan eta taldeka aplikatuta. Galdetegiaren egiturari erreparatuz, bi atal bereizten dira ikasleen galdetegian. Lehendabizikoa, 15 galderaz osatua: ikasleek zer neurritan uste duten lanbide-irteera bakoitza graduko irakasgaietan ordezkatuta dagoen, eta, irakasleen kasuan, zer eremurekin eta zer neurritan lotzen dituzten irakasgaiak. Erantzunak 1-5 puntuko Likert eskala baten bidez jaso dira. Bigarren atala, 14 galderaz osatua: ikasleriari bakarrik zuzendua, non galderen helburua den jakitea Pedagogia graduko ikasleen asebetetzea eta, espresuki, «lan orientazioaren» bilakaera eta azterketa (Likert eskala 1-4). Paperean nahiz online aplikatu da, eta ikasleek paperean bete dute; irakasleek, berriz, lineako modalitatean bete dute, hamabost minutuko iraupenarekin, gutxi gorabehera. Galdetegiaren fidagarritasunari dagokionez, .903ko Cronbach Alfa bat lortu zen, ikasle eta irakasleriak galdera berberak, 15, erantzun zituzten, galdetegiaren barne-sendotasuna bermatzen zelarik. 


\section{EMAITZAK}

\subsection{Pedagogiaren irteera profesionalak eta arlo horietan topatutako enpresak eremuen eta probintzien arabera}

1. taulan agertzen da Pedagogiako graduak zein esparru profesionaletara proiektatzen dituen ikasleak. Horretarako, hainbat enpresa eta erakunde posible identifikatu eta beren jarduna Hego Euskal Herrian kokatu da.

1. taula

Pedagogiako profesionalek lan egiteko aukera duten eremu, lanbide eta erakundeen adibideak

\begin{tabular}{|c|c|c|c|c|c|c|}
\hline \multicolumn{7}{|c|}{ 1. Ikerkuntza/Hezkuntza } \\
\hline & Ikerkuntza & Eduki Didaktik. & Berrikuntza & Orientazioa & Gabineteak & Zehaztu gabe \\
\hline Araba & ISEI-IVEI & Berrigasteiz & Ciurkide & $\begin{array}{l}\mathrm{BHI} \\
\text { mendebalde }\end{array}$ & $\begin{array}{l}\text { Izar } \\
\text { Kabinetea }\end{array}$ & Ibaizabal \\
\hline Bizkaia & Orientasare & Ibaizabal & Hikhasi & SOMA & Psikolan & Ibaizabal \\
\hline Gipuzkoa & Alecop & Elkar & Bakeola & Lugarizt & Harremanitz & Tknika \\
\hline Nafarroa & UNAV & Integratic & Ekilikua & Buztintxuri & $\begin{array}{l}\text { Hezitzaile } \\
\text { eskola }\end{array}$ & CREENA \\
\hline \multicolumn{7}{|c|}{ 2. Gizartea/Kultura } \\
\hline & Museoak & $\begin{array}{l}\text { Gizarte- } \\
\text { zerbitzua }\end{array}$ & Eleaniztasuna & $\begin{array}{c}\text { Gizarte } \\
\text { esku-hartzeak }\end{array}$ & Ezgai-tasuna & Zehaztu gabe \\
\hline Araba & Artium & $\begin{array}{l}\text { Arabako } \\
\text { foru aldundia }\end{array}$ & Learning-out & Irsearaba & Goizalde & Montehermoso \\
\hline Bizkaia & $\begin{array}{l}\text { EDE } \\
\text { fundazioa }\end{array}$ & GIZ Bermeo & $\begin{array}{l}\text { Hizkuntz } \\
\text { eskola }\end{array}$ & Agintzari & Aspace & Fekoor \\
\hline Gipuzkoa & San Telmo & Gizalde & HABE & Urtxintxa & Gureak & Untzimuseoa \\
\hline Nafarroa & Zubiondo & Navarra & Zubiarte & Ilundain & ANFAS & «La atalaya» \\
\hline \multicolumn{7}{|c|}{ 3. Formakuntza/Enpresa } \\
\hline & Bitartekaritza & e-Learning & $\begin{array}{c}\text { Formakuntza } \\
\text { enpresan }\end{array}$ & $\begin{array}{l}\text { Kudeaketa } \\
\text { enpresan }\end{array}$ & $\begin{array}{c}\text { Orient. } \\
\text { Sozio-laborala }\end{array}$ & Zehaztu gabe \\
\hline Araba & Ikaslan Araba & Berrigasteiz & Edukanature & SIA-SEA & Sartu (Araba) & Kontsumo-bide \\
\hline Bizkaia & $\begin{array}{l}\text { Ikaslan } \\
\text { Bizkaia }\end{array}$ & FFEuskadi & $\begin{array}{l}\text { Taupa- } \\
\text { Taupa }\end{array}$ & Izangai & AOSLA & Spri Taldea \\
\hline Gipuzkoa & $\begin{array}{l}\text { Ikaslan } \\
\text { Gipuzkoa }\end{array}$ & TAK & Dirdira & ECOI SS & Daiteke & Sartu \\
\hline Nafarroa & $\begin{array}{l}\text { Ode } \\
\text { consultoria }\end{array}$ & Dynamium & $\begin{array}{l}\text { Ode } \\
\text { consultoria }\end{array}$ & Talentix & Cederna & Zubeldia \\
\hline
\end{tabular}

Zikloan zehar, 2014an abiatutako graduari buruzko ikasleen pertzepzioa jasotzeko datu bilketa egiten jarraitu da 2019. urtera arte. Urtero lau- 
garren mailako ikasleei galdetegia eman zaie titulazioaren zenbait aspekturi buruzko balorazioa egin dezaten. Lan-orientazioaren dimentsioaren emaitzei dagokienez, lanketa-aro honen osteko bilakaera positiboa gertatu dela ikus daiteke, nabarmen gora egin duena (1,7ko balorazioa 2014ean) azken urteetan, eta bereziki 2019an 3,2 puntuazioarekin.

\section{Lan-orientazioa}

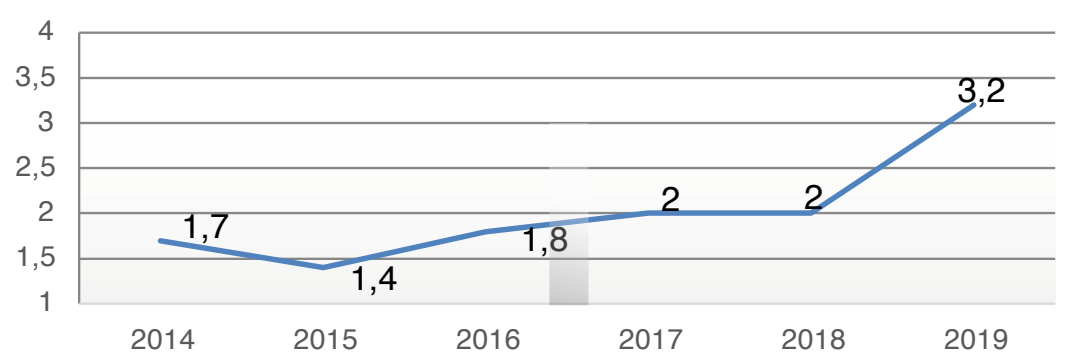

3. irudia

4. mailako ikasleen balorazioak, lan-orientazioari buruzkoak 2014-2019

4.2. Pedagogiako Graduko ikasgaiek zein eremu profesionaletarako prestatzen dute ikasleria? Ikasle eta irakasleen iritziak eta beren arteko ezberdintasunak

Eremu bakoitzaren lanbide-irteerak kontuan hartuz, ikasleriaren eta irakasleriaren erantzunen eta batez bestekoen arabera, argi ikus daiteke lehendabiziko eremurako («Hezkuntza eta ikerketa») gehiago ari direla prestatzen Pedagogiako Graduan.

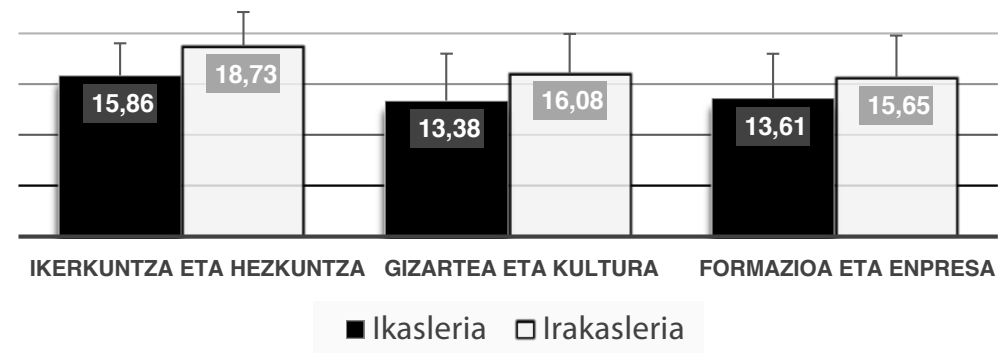

4. irudia

Ikasle-irakasleen arteko ezberdintasunak eremu profesionalarekiko 
Ikus daitekeenez (4. irudia), Pedagogiako graduko irakasleriak uste du pedagogiako ikasketak dezente prestatzen dituela hiru eremu profesionaletarako. Era berean, irakasleriak uste duena ez dator bat ikasleriak dioenarekin, ikasleek prestakuntza gutxiago izan dutela adierazten baitute.

Ezberdintasun horiek estatistikoki esanguratsuak dira, (ikusi 2. taula) nahiz eta ikasleriak hiru eremuetan nahiko lantzen direla adierazi, hiru eremuetan 2 eta 3 puntutik gorako aldea dago irakasleriaren eta ikasleriaren artean.

\section{2. taula}

\section{Ikasle-irakasleen arteko ezberdintasun estatistikoki esanguratsuak} eremu profesionalarekiko

\begin{tabular}{l|cc|cc|cccc}
\hline \multicolumn{1}{c|}{$\begin{array}{c}\text { Eremu } \\
\text { profesionalak }\end{array}$} & \multicolumn{2}{|c|}{$\begin{array}{c}\text { Ikasleria } \\
(\mathrm{N}=83)\end{array}$} & \multicolumn{2}{c|}{$\begin{array}{c}\text { Irakasleria } \\
(\mathrm{N}=48)\end{array}$} & t-student & $\mathrm{gl}$ & $\mathrm{Sig}$. & $\begin{array}{c}\text { Tamaina } \\
\text { efektua }\end{array}$ \\
\hline & $\mathrm{Bb}$ & $\mathrm{D} . \mathrm{T}$. & $\mathrm{Bb}$ & $\mathrm{D} . \mathrm{T}$. & $\mathrm{t}$ & $\mathrm{gl}$ & $\mathrm{p}$ & $\mathrm{d}-\mathrm{cohen}$ \\
\hline $\begin{array}{l}\text { Ikerketa eta } \\
\text { hezkuntza }\end{array}$ & 15.86 & 3.25 & 18,73 & 3,36 & 4,792 & 129 & .000 & .863 \\
$\begin{array}{l}\text { Gizartea eta } \\
\text { kultura }\end{array}$ & 13.38 & 3.95 & 16,08 & 3,85 & 3,796 & 129 & .000 & .682 \\
$\begin{array}{l}\text { Formakuntza } \\
\text { eta enpresa }\end{array}$ & 13.61 & 4.20 & 15,65 & 4,12 & 2,682 & 129 & .008 & .486 \\
\hline
\end{tabular}

Hau da, (2. taula), estatistikoki ezberdintasunak nabariak dira. Adibidez, «Ikerketa eta hezkuntza» eremuan, eta t-Student proga eginez, lortzen dira $\mathrm{t}(129)=4.792, p=.000$ eta tamainaren efektu altuarekin $(\mathrm{d}=.863)$. «Gizartea eta kultura» eremuan antzeko emaitzak lortzen dira $\mathrm{t}(1,129)=3.79$, $p=.000$ ezberdintasunarekin eta tamainaren efektu ertainarekin $(\mathrm{d}=.682)$; eta, azkenik, «Formakuntza eta enpresa» eremuan ere badira estatistikoki esanguratsuak diren ezberdintasunak $\mathrm{t}(1,129)=2.68, p=.008$, baina tamainaren efektu txikiagoarekin $(\mathrm{d}=.486)$.

Era berean, ikasleak eta irakasleak bat datoz pedagogiako ikasgaiak gehienbat «Hezkuntza eta ikerketa» irteera profesionalari bideratuta daudela. Horrela, «Gizartea eta kultura» eta «Formakuntza eta enpresa» eremuak atzetik datoz, gutxienez 2 puntu gutxiagorekin batez besteko guztietan.

\subsection{Pedagogiako Graduko ikasgaiek zein lanbide-irteerarako prestatzen dute ikasleria? Ikasle eta irakasleen iritziak eta beren arteko ezberdintasunak}

Pedagogoen lan anitzetatik 15 lanbide identifikatu dira graduaren irteera profesional egonkor gisa. Ikasleei galdetu zitzaien ea irakasgaiek zein puntutaraino prestatzen ote zituzten 15 lanbide horietarako. 
Pedagogiako irakasleriaren iritziei erreparatuz eta graduan zehar gehien prestatzen dituzten lanbide irteeren batez bestekoak aztertuz, hauek dira, alde batetik, puntuazio altuenak (3,70etik gora) jasotzen dituzten lanbideak: «4 Orientazio pedagogikoa ikastetxeetan» $(4,15)$; horren atzetik «1. Teoria pedagogikoa, ebaluazioa, ikerkuntza, unibertsitatea» $(3,79)$ eta «2. Diseinu kurrikularra eta material didaktikoen garapena» $(3,75)$. Beste alde batetik, baloraziorik baxuen dutenak (3tik behera) bi dira, nabarmen: «11. Ikaskuntza bitartekaritza zerbitzuak» $(2,92)$ eta «7. Zerbitzu pedagogikoak museoetan» $(2,54)$.

Ikasleriaren iritziei erreparatuz, galdetu zitzaien ea graduko irakasgaiek aipatu 15 lanbideetarako zenbat prestatzen ote zituzten. Batetik, puntuazio altuena (3,20tik gora) dute «1. Teoria pedagogikoa, ebaluazioa, ikerkuntza, unibertsitatea» $(3,72)$, «8. Esku-hartze zerbitzuak desgaitasunean» $(3,53)$ eta «4. Orientazio pedagogikoa ikastetxeetan» $(3,29)$ irteerek. Bestetik, lan hauetan aritzeko sentitzen dira gutxien (2,6tik behera) prestatuak: «6. Gizarte, hezkuntza eta kultura-zerbitzuak administrazioan» $(2,55)$, «13. IKT material formatiboen diseinua/ e-learning» $(2,33)$ eta «7. Zerbitzu pedagogikoak museoetan» $(1,75)$.

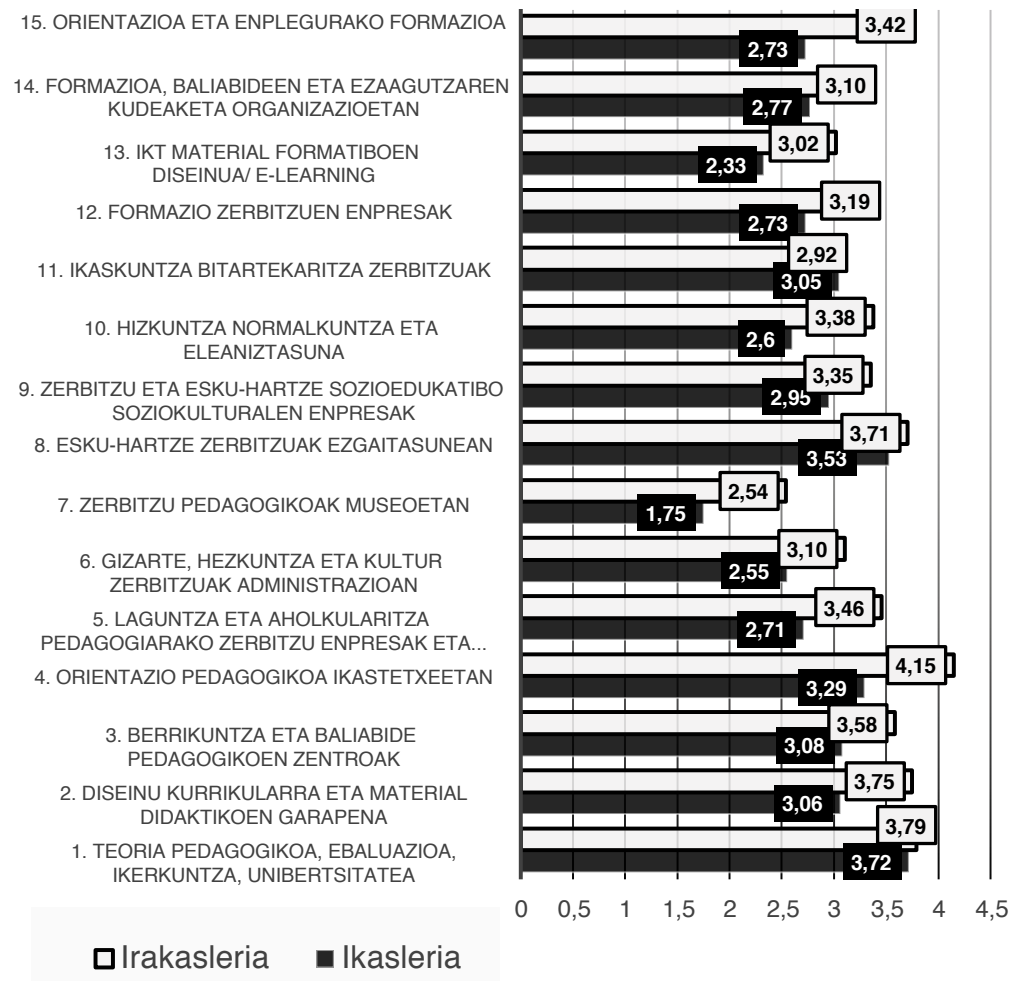

5. irudia

Ikasle-irakasleriaren arteko ezberdintasunak lanbide irteerekiko prestakuntzan 
Ikasle eta irakasleak bat datoz adierazten dutenean graduak ez dituela lanbide guztietarako berdin prestatzen: ikasgai batzuetan lanketa askoz urriagoa da bestetan baino. Alabaina, bi eragile horien batez bestekoei erreparatuz, alde nabarmena sumatzen da irakasle eta ikasleriaren artean. Hau da, irakasleriaren batez bestekoak altuagoak dira ikasleen balorazioak baino.

$\mathrm{Bi}$ eragile horien arteko ezberdintasunak estatistikoki esanguratsuak ote diren aztertzeko t-Student froga egin da.

\section{3. taula}

Ikasle-irakasleriaren arteko ezberdintasunak lanbide irteerekiko

\begin{tabular}{|c|c|c|c|c|c|c|c|}
\hline \multirow[t]{2}{*}{ Itemak } & \multicolumn{2}{|c|}{$\begin{array}{c}\text { Ikasleria } \\
(\mathrm{N}=83)\end{array}$} & \multicolumn{2}{|c|}{$\begin{array}{l}\text { Irakasleria } \\
(\mathrm{N}=48)\end{array}$} & \multirow{2}{*}{\begin{tabular}{|c}
$\mathrm{t}$-Student \\
$\mathrm{t}$ \\
\end{tabular}} & \multirow{2}{*}{$\begin{array}{c}\text { Sig.. } \\
p\end{array}$} & \multirow{2}{*}{$\begin{array}{c}\text { Efektu } \\
\text { Tam. }\end{array}$} \\
\hline & $\mathrm{Bb}$ & DT & $\mathrm{Bb}$ & DT & & & \\
\hline $\begin{array}{l}\text { 1. Teoria pedagogikoa, ebaluazioa, } \\
\text { ikerkuntza, unibertsitatea }\end{array}$ & 3.72 & .860 & 3.79 & .944 & .425 & 671 & - \\
\hline $\begin{array}{l}\text { 2. Diseinu kurrikularra eta material } \\
\text { didaktikoen garapena }\end{array}$ & 3.06 & .929 & 3.75 & 1.158 & 3.52 & $.000 * * *$ & .673 \\
\hline $\begin{array}{l}\text { 3. Berrikuntza eta baliabide pedago- } \\
\text { gikoen zentroak }\end{array}$ & 3.08 & .913 & 3.58 & 1.007 & 2.90 & $.004 * *$ & .524 \\
\hline $\begin{array}{l}\text { 4. Orientazio pedagogikoa ikastetxee- } \\
\tan \end{array}$ & 3.29 & 1.153 & 4.15 & .850 & 4.85 & $.000 * * *$ & .812 \\
\hline $\begin{array}{l}\text { 5. Laguntza eta aholkularitza peda- } \\
\text { gogiarako zerbitzu enpresak eta } \\
\text { kabineteak }\end{array}$ & 2.71 & 1.110 & 3.46 & .898 & 3.97 & $.000 * * *$ & .718 \\
\hline $\begin{array}{l}\text { 6. Gizarte, hezkuntza eta kultur zer- } \\
\text { bitzuak administrazioan }\end{array}$ & 2.55 & 1.015 & 3.10 & 1.115 & 2.88 & $.005^{* *}$ & .519 \\
\hline 7. Zerbitzu pedagogikoak museoetan & 1.75 & 1.069 & 2.54 & 1.414 & 3.37 & $.000 * * *$ & .650 \\
\hline $\begin{array}{l}\text { 8. Esku-hartze Zerbitzuak ezgaitasu- } \\
\text { nean }\end{array}$ & 3.53 & 1.040 & 3.71 & .874 & 1 &, 319 & - \\
\hline $\begin{array}{l}\text { 9. Zerbitzu eta esku-hartze sozio-he- } \\
\text { zitzaile soziokulturalen enpresak }\end{array}$ & 2.95 & 1.070 & 3.35 & .934 & 2.17 & $.032 *$ & .388 \\
\hline $\begin{array}{l}\text { 10. Hizkuntza normalkuntza eta elea- } \\
\text { niztasuna }\end{array}$ & 2.60 & 1.136 & 3.38 & 1.142 & 3.74 & $.000 * * *$ & .681 \\
\hline 11. Ikaskuntza bitartekaritza zerbitzuak & 3.05 & .987 & 2.92 & 1.088 & .708 & .480 & - \\
\hline 12. Formakuntza zerbitzuen enpresak & 2.73 & 1.094 & 3.19 & 1.085 & 2.28 & $.024 *$ & .419 \\
\hline $\begin{array}{l}\text { 13. IKT material formatiboen disei- } \\
\text { nua/ e-learning }\end{array}$ & 2.33 & 1.072 & 3.02 & 1.101 & 3.54 & $.001 * *$ & .633 \\
\hline $\begin{array}{l}\text { 14. Formakuntza, baliabideen eta eza- } \\
\text { gutzaren kudeaketa organizazioetan }\end{array}$ & 2.77 & 1.028 & 3.10 & .973 & 1.82 & 0.70 & - \\
\hline $\begin{array}{l}\text { 15. Orientazioa eta enplegurako for- } \\
\text { makuntza }\end{array}$ & 2.73 & 1.083 & 3.42 & 1.069 & 3.488 & $.001 * *$ & .636 \\
\hline
\end{tabular}

Ezberdintasun esanguratsuak $* \mathrm{p}<.05 ; * * \mathrm{p}<.01 ; * * * \mathrm{p}<.001$ 
Taulari kasu eginez (3. taula), 15 lanbide irteeretatik 11tan topatzen ditugu ezberdintasun estatistikoki esanguratsuak (ikusi $* p<.05 ; * * p<.01$; $* * * p<.001)$. Are gehiago, 15 horietatik 5en kasuan estatistikoki ezberdintasun esanguratsu oso altuak dira (itemak 2, 4, 5, 7 y 10,***p<.001); 4tan, desberdintasun altuak (itemak 3,6,13 y 15, **p<.01) eta 2 kasutan, desberdintasun estatistiko esanguratsuak soilik (itemak 9 y $12 * p<.05$ ). Horiei guztiei tamainaren efektua kalkulatu zaie, eta kasu gehienetan topatu da horien tamaina altua edo ertaina dela d >.5 (Cohen, 1988).

Irakasleriaren eta ikasleriaren datuak alderatzen badira, ikus daiteke irakasleek lanbideetarako behar den prestakuntza gehiago puntuatzen dutela ikasleriak baino. Edo, alderantziz, ikasleriak beti baloratzen duela gutxiago, irakasleriarekin alderatuta, lanbide guztietarako jasotzen duten prestakuntza. Hamaika ezberdintasun estatistikoki esanguratsuetatik, hona hemen nabarmenenak eremuka:

Lehendabiziko eremuan, «Ikerketa eta hezkuntza» (itemak: 1etik-5era): 5 item horietatik 4tan estatistikoki ezberdintasunak daude eta, batez ere, «4. Orientazio pedagogikoa ikastetxeetan» $\mathrm{t}=4.859, p<.001 * * *$ eta tamaina efektu altu batekin $(\mathrm{d}=.812)$, eta « 5. Laguntza eta aholkularitza pedagogiarako zerbitzu enpresak eta kabineteak» $\mathrm{t}=3.971, p<.001 * * *$ eta tamaina efektu altuarekin (d=.718). Ez litzateke alderik egongo item honetan: «1. Teoria pedagogikoa, ebaluazioa, ikerkuntza, unibertsitatea».

Bigarren eremuari kasu eginez, «Gizartea eta kultura» (itemak: 6etik-10era): berriro 5 item horietatik 4 tan ezberdintasun esanguratsuak topatzen dira. Aipatzekoak dira «7. Zerbitzu pedagogikoak museoetan» $\mathrm{t}=3.376, p<.001 * * *$ eta tamaina efektu ertain batekin $(\mathrm{d}=.650)$ eta $\ll 10$. Hizkuntza normalkuntza eta eleaniztasuna» $\mathrm{t}=3.743, p<.001 * * *$ tamaina efektu nabariarekin $(\mathrm{d}=.681)$. Bestalde, ez legoke ezberdintasunik «8. Esku-hartze zerbitzuak ezgaitasunean» irteera profesionalean.

Azkenik, hirugarren eremuan, «Formakuntza eta enpresa» (itemak: 11etik-15era): 5 item horietatik 3 tan nabariak dira ezberdintasunak. Bi kasu hauetan, «13. IKT material formatiboen diseinua/ e-learning» $\mathrm{t}=3.54$, $* * p<.01 ;(\mathrm{d}=.633)$ eta $\ll 15$. Orientazioa eta enplegurako formakuntza» $\mathrm{t}=3.488 * * p<.01 ;(\mathrm{d}=.636)$, ezberdintasunak esanguratsuak dira, eta biek dute efektuaren tamaina ertaina. Aldiz, ez da desberdintasun estatistikorik aurkitu «11. Ikaskuntza bitartekaritza zerbitzuak» eta «14. Formakuntza, baliabideen eta ezagutzaren kudeaketa organizazioetan» itemetan.

\section{ONDORIOAK, EZTABAIDA ETA ETORKIZUNEKO LAN- LERROAK}

Jakinik ikasleen prestakuntza GHEEren eskakizunetara egokitzeko ahalegin handiak egiten ari direla, ikerketa honetan lortutako emaitzek, nagusiki, erakusten dute unibertsitateak lanean jarraitu behar duela GHEE- 
ren barruan kalitatezko prestakuntza lortzeko (Biggs, 2005; Rieira y Civís, 2008; González-Lorente et al., 2015). Are indar handiagoz, Pedagogiak bezala, izaera plurala eta konplexua duten graduetan, zeinetan diziplina jakintza anitzen eraikuntza artikulatzaile gisa egin behar den.

Ikerketan finkatutako helburuak bete ahal izan dira hein handi batean. Alde batetik, ezagutu ahal izan dugu ikasleen ustez graduan jasotzen duten prestakuntzak etorkizuneko zein esparru profesionaletara proiektatzen duen gehien («teoria, ebaluazioa, ikerkuntza», edota «esku-hartze zerbitzuak ezgaitasunean») euren ibilbide formatiboa, eta zein esparrutara gutxien («zerbitzu pedagogikoak museotan»). Bestetik, ikasleek eta irakasleek graduan emandako prestakuntzan lanbide-irteeren lanketari buruz duten pertzepzioan dauden aldeak ere identifikatu ahal izan dira, eta ikusi ahal izan da badaudela ezberdintasun esanguratsuak hainbat kasutan (esate baterako, irakasleek gehiago puntuatzen dute «laguntza eta aholkularitza pedagogikorako zerbitzu enpresak eta kabineteak» edota «IKT material formatiboen diseinua/e-learning» lanbide-esparruei begira graduan zehar ematen den prestakuntza ikasleek baino, eta ikasleek beti baloratzen dute gutxiago lanbiderako jasotzen duten prestakuntza).

Aitzitik, irakasle bakoitzak lantzen dituen irakasgaiak zein esparru profesionaletan hautematen dituen aztertzeari buruzko hirugarren helburuari dagokionez, datuak jaso badira ere, ez dute aski kontsistentzia izan emaitza esanguratsuak ondorioztatu ahal izateko. Hau da, hain zuzen ere, aurrerantzean ikerketa berrietan sakontzeko irekia gelditzen den aztergaia.

Egun pedagogoaren irteera profesionalen eremuan dagoen ikusgarritasun sozialaren defizita seinalatu da, eta horregatik PedaLan bezalako lan-ildoetan lanean jarraitzeko beharra azpimarratzen da. Proiektu honek baldintzak sortzen baititu tokiko ezagutza sortzeaz batera, Pedagogia graduan lanbideen errepresentazioari lotutako eskaintza formatiboa indartzeko. Orain artean norabide horretan egindako ahaleginek beren uzta eman dute: ikasleek graduan zehar jasotako lan-orientazioari buruzko pertzepzioak nabarmenki egin du gora. Hobekuntza esfortzu hauek aski izatetik urruti, hein batean, unibertsitatetik agertokiak eraikitzen dituzte jendartean pedagogoaren irudi soziala definitzen eta hobetzen laguntzeko (Touriñan, 2018).

Etorkizun hurbilera begira, bada Pedagogiako graduan zer hobetu baldin eta ikasleen beharrei, euskal jendartearen erronkei eta lan merkatuari egokitutako formakuntza praktikoagoa eta errealistagoa eskaini nahi bada. Pedagogiaren profesionalizazio maparen kontrasteak hausnarketa hori ireki du: irakasleriak eta baita ikasleriak ere sentitzen du «Ikerkuntza eta Hezkuntza» graduan neurriz gain irudikatua dagoela eta orain, eremu sozial, kultural edota enpresakoa nola landu aztertzea tokatzen da. Rierak eta Civísek (2008) aztertzen duten trantsizio pedagogiko nagusiari erreparatuz, eskolatzetik eta oinarrizko irakaskuntzatik gizarte eta hezkuntza sare zabalago batera igaro nahi badugu. 
Agerian geratu da, hortaz, graduak ez duela lanbide-eremu anitzetarako berdin prestatzen, eragileen iritziz badirelako arreta gehiago eskaintzen zaien lanbideak edota horietara nabarmenki bideratzen diren ikasgaiak. Emaitza horiek pentsarazten digute ikasleria gero eta gehiago jabetzen dela graduan lanbideen errepresentazioak duen garrantziaz eta beste ikerketa batzuetan azpimarratzen den bezala (Fuentes, 2008; De Juanas eta Beltrán, 2014) unibertsitate-formakuntza osoagoa eta hobea eskatzen duela irakasleriak duen pertzepzioaren gainetik.

Izan ere, bi eragile horien batez bestekoei erreparatuz, alde esanguratsua topatzen dugu irakasle eta ikasleriaren artean. Hau da, irakasleriaren eta ikasleen balorazioak konparatuz irakasleenak balio altuagokoak dira eta ikasleek pentsatzen dutena baino prestakuntza gehiago ematen dutela uste dute irakasleek. Beste autore batzuen ikerketan gertatzen den bezala, ebaluatze eta ikasketa maila aztertzean, ikasle eta irakasleriaren pertzepzioa desberdinak dira (Smimou eta Dahl, 2012). Gauza bera gertatzen da irakaskuntza gaitasunen garapenaren kasuan (Lorente-Catalán, Reina, Pérez, Noguerola eta Vilalta, 2017) edota prestakuntzaren ebaluazioan (Ruiz-Gallardo, Lara eta Ortín, 2013). Agian bi eragile hauen arteko aldea murrizteko asmoz, eragile hauen arteko bilera eta talde eztabaida sustatu behar da, graduaren hobekuntzarako eta ikasleriaren prestakuntza benetan errealitatearekin bat egiteko eta gaurkotua izateko.

Esandako guztia kontutan hartuz, egin den azterketaren izaera zehatza eta mugatua da, eta, kontuan hartu behar dira azterketaren mugak eta, horiekin batera, orokortzeak eta/edo ondorioak ezartzean sor daitezkeen zailtasunak. Muga horien artean, nabarmentzekoa da beharrezkoa dela informazioa zabaltzea eta ikasleen zein irakasleen ikuspegia eta esperientzia osatzea inplikatutako beste gizarte- eta hezkuntza-eragile batzuenarekin, hezkuntza-enplegatzaile edota kudeatzaileenarekin, esaterako. Alta, deskribatutako muga hori, berez, etorkizuneko ikerketa-ildoetariko bat da.

Artikulua hau amaitzen ari garenean, COVID-19ak eragindako dimentsio anitzeko etenaldiarengatik, gure unibertsitatea irakaskuntza- eta lineako ikaskuntza-jarduera erraldoiarekin ari da aurrera egiten. Honek Pedagogiako graduaren eskaintza formatiboari begira zer pentsatua ematen du IKTetan eta eLearning formakuntzan trebeak beharko luketen profesionalen profila bermatzearren. Espero dezagun krisi honi aurre egiteko, urteetan metatutako esperientziak eta sortutako ezagutzak aukera ematea unibertsitatearen etorkizuneko erronkei aurreko etapetan baino modu egokiago batean heltzeko.

Bien bitartean, Pedagogiaren etorkizuna gradu gisa, hein handi batean profesionalizazioaren eta profesionalismoaren mende egongo da, eta, biharko Pedagogiak ezinbesteko ardura dauka ziurgabetasunezko garaiotan hain beharrezkoa den kalitatezko hezkuntzarekiko etengabeko harremana jorratzeko. Artikulu honekin pauso bat eman nahi izan dugu norabide horretan. 


\section{ERREFERENTZIAK}

ANECA. (2005). Libro Blanco. Título de grado en pedagogía y educación social. (Vol. 1). Madril: Agencia Nacional de la calidad y la acreditación.

Aramburuzabala, P. (2012). El pedagogo laboral. Un experto en aprendizaje en las organizaciones. In A. De la Herrán (kord.), Apuntes de Pedagogía: la figura del pedagogo, hoy (20-21). Madril: Colegio Profesional de la Educación.

Benedito, V., Millan i Guasch, M.D. eta Amadó, N. (1986). Els Llicenciats en pedagogia per la Universitat de Barcelona: anàlisi de les sortides professionals. PPU.

Biggs, J. (2005). Calidad del aprendizaje universitario. Madril: Narcea.

Boulton, G., eta Lucas, C. (2011). What are universities for?. Chinese Science Bulletin, 56(23), 2506-2517.

Cardona, J. (2011). Hacia la mejora de la formación práctica del estudiante de pedagogía en la UNED. Educación XX1, 14(2), 303-330.

Cohen, J. (1988). Statistical power analysis for the behavioral sciences, 2nd ed. Hillsdale, NJ: Erlbaum.

De Juanas Oliva, Á. eta Beltrán Llera, J.A. (2014). Valoraciones de los estudiantes de ciencias de la educación sobre la calidad de la docencia universitaria. Educación XX1, 17 (1), 57-82. doi:10.5944/educxx1.17.1.10705.

Collini, S. (2012). What are universities for? . Penguin UK.

Dendaluze, I. (1999). La investigación educativa ante el tercer milenio. Bordón, 51(4), 363-376.

Europako Batzordea. (2015). ECTS Users' Guide. Luxemburgo: Oficina de Publicaciones Oficiales de la Unión Europea.

Eizagirre, A., Altuna, J., Pikabea, I., Marko, J. I. eta Pérez, V. (2017). Las competencias transversales en el grado de Pedagogía: diagnóstico y estado de la cuestión. REDU Revista de Docencia Universitaria, 15(1), 259-276.

Fernández-Salinero, C. eta de la Riva, B. (2016). La Pedagogía Laboral como especialidad profesional en el siglo XXI. Revista española de pedagogía, 265, 559-577.

Figueroa, I. eta Gomez, M. P. (2015). Cuestionar y problematizar la propia práctica: Investigación Acción Transformadora en los procesos de desarrollo profesional docente. Summa Psicológica UST, 12(2), 31-42.

Fuentes, L. (2008). Demandas de los titulados universitarios. In AA.VV., Competencias genéricas y transversales de los titulados universitarios (19-27). Zaragoza: ICE de la Universidad de Zaragoza.

Fullan, M. (2002). Las fuerzas del cambio (5. bol). Ediciones Akal.

García-Alvarez, J., Sotelino, A., eta Crespo, J. M. (2014). Prospects for Social Employment Insertion of Graduates in Pedagogy in the Autonomous Community of Galicia. From the University to the Labour Market. Procedia-Social and Behavioral Sciences, 139, 412-418.

González-Lorente, C., Martínez-Clares, P., eta González-Morga, N. (2015). El perfil formativo del graduado en pedagogía: La visión del alumnado. Profesorado, Revista de Currículum y Formación del Profesorado, 19(1), 394-412.

Hargreaves, A. (1999). Profesorado, cultura y postmodernidad. Cambian los tiempos, cambia el profesorado. 3. edizioa. Morata.

Hernández, R., Fernández, C., eta Baptista, P. (2006). Metodología de la Investigación. 4. edizioa. Ed. Ciudad de México, México: McGrawl Hill. 
Herrán de la, A. (2012). Currículo y pedagogías renovadoras en la edad antigua. REICE. Revista Iberoamericana sobre Calidad, Eficacia y Cambio en Educación, 10(4), 285-334.

Kerlinger, F. N. (1983). Foundations of behavioral research. 2nd Indian reprint. Edition New Delhi.

Knowles, M. (1972). Andragogía no pedagogía. Centro Regional de Educación de Adultos. Temas de Educación de Adultos, 1(2).

Kemmis, S. eta McTaggart, R. (1988). Cómo planificar la investigación-acción. Barcelona: Laertes.

Lorente-Catalán, E., Reina, M. J. M., Pérez, A. J., Noguerola, A. G. eta Vilalta, D. C. (2017). ¿Perciben del mismo modo alumnado y profesorado el desarrollo de competencias docentes? El caso de un grado de ciencias de la actividad física y el deporte. Revista Infancia, Educación y Aprendizaje, 3(2), 588-593.

Marko, I. eta Altuna, J. (2016). La profesionalización del/a pedagogo/a: construyendo un Mapa de Orientación. In Democracia y Educación en el siglo XXI. La obra de John Dewey 100 años después: libro de actas del XVI Congreso Nacional y VII Congreso Iberoamericano de Pedagogía [celebrado del] 28 al 30 de junio de 2016, Facultad de Educación, Universidad Complutense de Madrid (54-55). Sociedad Española de Pedagogía.

Marko, I., Pikabea, I., Altuna, J., Eizagirre, A. eta Perez-Sostoa, V. (2019). Propuesta para el desarrollo de competencias transversales en el Grado de Pedagogía. Un estudio de caso. Revista Complutense de Educacion, 30(2), 381-399.

Marquand, J. eta Scott, P. (2018). The Bologna Declaration of 19 June 1999, Democrats, Authoritarians and the Bologna Process, Emerald Publishing Limited, pp. 183-186. https://doi.org/10.1108/978-1-78743-439-420181009

MEC (2006). Borrador de propuesta. Directrices para la elaboración de títulos universitarios de grado y máster. Madril: MEC.

MEC (2008). Principios y orientaciones prácticas para el diseño de estudios de Grado, Máster y Doctorado, según el R.D. 1393/2007 de ordenación de las enseñanzas universitarias. Estudio EA2008-0292. Convocatoria MEC de «Estudios y Análisis» 2008 (BOE n. ${ }^{\circ} 31$ de 5/2/2008). Madril: MEC.

Navarrete, Z. (2008). Construcción de una identidad profesional: los pedagogos de la Universidad Nacional Autónoma de México y de la Universidad Veracruzana. Revista mexicana de investigación educativa, 13(36), 143-171.

Pineda, P. (2002). Gestión de la formación de las organizaciones. Bartzelona: Ariel

Pineda, P., Ciraso, A. eta Armijos, M. (2018). Competencias para la empleabilidad de los titulados en Pedagogía, Psicología y Psicopedagogía: un estudio comparativo entre empleadores y titulados. Revista española de pedagogía, 76(270), 313-334.

Riera i Romaní, Jordi, eta Civís i Zaragoza, Mireia (2008). La pedagogía profesional del siglo XXI. Educación XX1, 11,133-154.[Kontsulta-data 2020-05-12]. Hemendik hartua: https://www.redalyc.org/articulo.oa?id=706/70601107

Rosales, S. T., Torres, M. H., Sánchez, M. T. P., Jiménez, C. F., eta Cabezas, M. F. (2018). El perfil formativo y profesional del graduado en pedagogía. Perspectiva actual de su inserción laboral. Revista INFAD de Psicología. International Journal of Developmental and Educational Psychology., 2(1), 295-306. 
Ruiz de Miguel, C., eta García de la Barrera, M. J. G. (2013). Inserción laboral de los licenciados en pedagogía de la Universidad Complutense de Madrid (2006-2012): cómo, dónde y cuánto tarden en colocarse los pedagogos. In Investigación e Innovación Educativa al Servicio de Instituciones y Comunidades Globales, Plurales y Diversas (1206-1213). Universitat d' Alacant/Universidad de Alicante.

Ruiz-Gallardo, J. R., Lara, E. R. eta Ortín, N. U. (2013). La evaluación en la formación inicial del profesorado: qué creemos hacer y qué perciben los alumnos.(The assessment in initial teacher training: what we do and what students perceive). Cultura, ciencia y deporte, 8(22), 17-29.

Sánchez Morales, P. J., eta Vega, F. (2019). Pedagogía laboral: Antecedentes históricos y situación actual de los profesionales.Etic@ net: Revista científica electrónica de Educación y Comunicación en la Sociedad del Conocimiento, 19(2), 74-99.

Smimou, K., eta Dahl, D. W. (2012). On the relationship between students' perceptions of teaching quality, methods of assessment, and satisfaction. Journal of Education for Business, 87(1), 22-35.

Torres Sabaté, M. C. (2015). El perfil del profesional de la pedagogía ante los retos del S. XXI. In Cultura emprendedora y educación (83-94). Universidad de Sevilla.

Touriñan, J. M. (2018). Imagen social de la pedagogía (disciplina científica y carrera). Revista Boletín Redipe, 7(9), 32-55.

Townsend, M. (2012). Are we making the grade? The education of children and young people in out-of-home care. Australia: NSW Department of Family and Community Services.

Viladot, G. (1992). La Proyección profesional del pedagogo en la empresa. Apuntes para una pedagogía empresarial. Bartzelona: Universidad Autónoma de Barcelona, Servicio editorial.

Villa, A. (2004). Libro blanco: Título de grado en pedagogía y educación social. Madril: ANECA.

Viñao, A. (2008). La escuela y la escolaridad como objetos históricos. Facetas y problemas de la historia de la educación. Espacios en Blanco. Revista de Educación, 18, 39-78. 